\title{
KAJIAN MANFAAT GERBONG KHUSUS WANITA DI KRL COMMUTER LINE JABODETABEK
}

\author{
Jonathan Saliman ${ }^{1}$ dan Leksmono Suryo Putranto ${ }^{2}$
}

\author{
${ }^{1}$ Program Studi Sarjana Teknik Sipil, Universitas Tarumanagara, Jl. Letjen S. Parman No.1 Jakarta \\ Jonathan.325160094@stu.untar.ac.id \\ ${ }^{2}$ Program Studi Sarjana Teknik Sipil, Universitas Tarumanagara, Jl. Letjen S. Parman No.1 Jakarta \\ leksmonop@ft.untar.ac.id
}

\begin{abstract}
Trains are one of the modes of public transportation that are widely used by the public. Travel by train has many advantages. To answer the needs of its users, PT Kereta Api Indonesia (KAI) develop Kereta Rel Listrik (KRL) Commuter Line which is a commuter railway service that is operated by PT KAI. Since 1 October 2012, PT Kereta Api Indonesia (Persero) Commuter Jabodetabek (Greater Jakarta) launched a special train carriage of women. The existence of this special train cariage is intended for women who use public transport to avoid criminal acts, sexual harassment etc. However, after the operation of women-only carriages in KRL complaints from female passengers using the carriage facilities reappeared. This article aims to analyze existing conditions and infrastructure of KRL Commuter Line with one sample T Test and analyze the efforts that can be done to improve the quality of women mobility using KRL with the Analytical Hierarchy Process. In general, except for train capacity, the resepondents were satisfied. For women mobility quality improvement using KRL, most of the respondents suggest additional train frequency.
\end{abstract}

Keywords: Benefit study; women's special train carriage; KRL; Greater Jakarta

\begin{abstract}
ABSTRAK
Kereta api adalah salah satu moda transportasi publik yang banyak digunakan oleh masyarakat. Perjalanan menggunakan kereta api memiliki banyak keuntungan. Untuk menjawab kebutuhan para pengguna nya PT Kereta Api Indonesia (KAI) mengembangkan Kereta Rel Listrik (KRL) Commuter Line yang merupakan layanan kereta rel listrik komuter yang pengoperasiannya dilakukan oleh PT Kereta Commuter Indonesia. Sejak 1 Oktober 2012, PT KAI (Persero) Commuter Jabodetabek meluncurkan kereta khusus wanita. Keberadaan gerbong khusus wanita ini pada dasarnya dimaksudkan agar wanita yang menggunakan angkutan umum terhindar dari tindakan kriminal, pelecehan seksual dll. Namun setelah beroperasinya gerbong khusus wanita pada KRL, muncul kembali keluhan dari para penumpang wanita yang menggunakan fasilitas gerbong tersebut. Tulisan ini bertujuan untuk menganalisis kondisi eksisting sarana dan prasarana KRL Commuter Line dengan metode one sample T Test dan menganalisis upaya yang dapat dilakukan untuk meningkatkan fasilitas gerbong khusus wanita dengan metode Analytical Hierarchy Process. Secara umum, kecuali terkait kapasitas kereta, responden merasa telah puas dengan layanan KRL. Untuk peningkatan kualitas mobilitas wanita yang menggunakan KRL, sebagian besar responden menyarankan penambahan frekuensi kedatangan kereta.
\end{abstract}

Kata Kunci: Kajian Manfaat; Gerbong Khusus Wanita; KRL; Jabodetabek

\section{PENDAHULUAN}

Dahulu, para wantia mengalami hambatan dalam meraih impian dan cita-cita mereka, serta kurang mendapat perlakuan dan kesempatan yang sama dengan laki-laki, seperti dalam hal pekerjaan. Dewasa ini, hal- hal tersebut tidak lagi terjadi pada wanita. Sebagian besar wanita sudah mendapatkan perlakuan dan kesempatan yang setara dengan laki- laki. Di era modern ini, banyak profesi yang awalnya tidak lazim untuk dikerjakan oleh wanita, tetapi sekarang sudah tak lagi jarang untuk mereka kerjakan, terlebih lagi, di kawasan Jabodetabek. Wanita membuat perjalanan yang lebih kompleks daripada pria dan layanan transportasi yang baik memberikan kesempatan kepada wanita seperti pekerjaan, pengasuhan anak, pendidikan dan fasilitas kesehatan (Babinard 2010). Untuk menjawab kebutuhan para pengguna nya PT KAI membentuk KRL Commuter Line. Layanan transportasi umum ini juga dikenal dengan nama 
KRL Jabodetabek. KRL Commuter Line ini merupakan layanan kereta rel listrik komuter yang pengoperasiannya dilakukan oleh PT Kereta Commuter Indonesia.

Setelah beroperasinya gerbong khusus wanita pada KRL, muncul kembali keluhan dari para penumpang wanita yang menggunakan fasilitas gerbong tersebut. Para penumpang wanita seringkali harus mengalami kejadian tidak mengenakkan seperti berdesak-desakan secara tidak tertib saat masuk dan keluar gerbong (mereka tidak tertib untuk mengantre). Tidak jarang para penumpang harus saling beradu mulut dan bahkan ada kasus dua wanita saling jambak demi mendapat tempat duduk. Belum lagi pada jam sibuk seperti pagi hari saat berangkat kerja dan sore hari saat jam pulang kerja, jumlah penumpang meningkat sehingga harus berdesak-desakan mulai dari stasiun saat menunggu kereta datang. Para penumpang wanita seolah-olah tidak boleh lengah sedikitpun atau mereka akan melewatkan kesempatan untuk duduk atau bahkan naik ke gerbong.

Para wanita hamil dan lansia juga seringkali tidak mendapatkan kesempatan untuk duduk di kursi prioritas karena penumpang lain yang tidak mau mengalah. Untuk itu, banyak penumpang yang harus menyiapkan sejumlah srategi agar dapat menggunakan fasilitas gerbong khusus wanita ini. Tidak sedikit pula yang memilih untuk naik di gerbong umum bersama laki-laki karena merasa akan diprioritaskan untuk mendapat tempat duduk.

Masalah selanjutnya yang dialami oleh penumpang wanita saat melakukan perjalanan adalah, pada pagi hari mereka tidak jarang memilih untuk naik di gerbong umum walaupun harus berdesak-desakan dengan penumpang laki-laki sekalipun. Hal ini dikarenakan para wanita menilai hal ini masih cukup nyaman di lakukan pada pagi hari karena para penumpang dinilai masih cukup segar dan tidak mengeluarkan bau badan. Hal ini berbeda dengan keadaan di sore hari, setelah melakukan aktivitas seharian, timbul bau yang kurang mengenakkan umumnya dari kaum laki-laki karena kaum laki-laki cenderung lebih tidak merawat diri dibandingkan kaum wanita. Segelintir penumpang lainnya, seperti wanita hamil (khususnya yang postur tubuhnya kecil) seringkali diragukan kondisinya dan tidak diberikan tempat duduk prioritas. Mereka kemudian merencanakan strategi khusus untuk mendapatkan tempat duduk. Contoh konkretnya yaitu ada penumpang wanita yang naik dari Stasiun Cikini dengan tujuan akhir Stasiun Depok, mereka memilih untuk terlebih dahulu balik arah menuju Stasiun Kota dan memastikan mendapat tempat duduk karena stasiun tersebut merupakan stasiun awal, sehingga penumpang akhirnya bisa duduk hingga ke stasiun tujuan Stasiun Depok.

Batasan Masalah pada penelitian ini:

1. Responden wanita adalah pengguna KRL yang sudah pernah menggunakan gerbong khusus wanita.

2. Responden baik pria maupun wanita adalah pengguna KRL Jabodetabek sehari-hari.

Berdasarkan masalah yang dirumuskan pada rumusan masalah, maka tujuan dari penulisan topik ini adalah:

1. Mengetahui keadaan dan situasi nyata saat bertransportasi menggunakan KRL di Jabodetabek.

2. Memperoleh cara untuk meningkatkan pelayanan dari KRL agar wanita nyaman dan memilih untuk bertransportasi menggunakan KRL.

\section{Kualitas pelayanan kereta api}

Ispurwanto dan Pricilla pada tahun 2011 pernah melakukan penelitian yang berjudul "Analisis Kepuasan Penumpang Gerbong Kereta Api Khusus Wanita Menggunakan Model Servqual". Tujuan dari penelitian tersebut adalah mengetahui gambaran/tingkat kepuasaan penumpang wanita terhadap pelayanan gerbong khusus wanita pada rute perjalanan Bogor-Jakarta. Hasil penelitian yang didapat menunjukan bahwa secara keseluruhan penumpang merasa tidak puas pada pelayanan gerbong khusus wanita. Walaupun ada juga layanan yang dirasa cukup memuaskan seperti dimensi kualitas pelayanan. Dimensi ini terdiri dari empati, kemudahan, kenyamanan dan jaminan. Respoden dari penelitian ini berjumlah 80 orang penumpang kereta api Bogor-Jakarta. Responden berusia antara 12 sampai 49 tahun dengan jenis kelamin wanita.

Dapat dikatakan bahwa penumpang memiliki pandangan yang rendah terhadap kualitas pelayanan gerbong kereta api khusus wanita. Dari analisis data yang dilakukan diperoleh hasil bahwa penumpang kereta api gerbong khusus wanita secara umum merasa tidak puas terhadap pelayanan yang diberikan oleh pengelola kereta api.

Ketidakpuasan yang dirasakan oleh penumpang berkaitan dengan dimensi koneksi, reliabilitas, daya tanggap, dan bukti fisik. Yang paling dirasakan tidak memuaskan adalah dimensi koneksi. Yang termasuk ke dalam dimensi koneksi yaitu ketersediaan lapangan parkir, kemudahan akses ke stasiun dan frekuensi kereta api. Sedangkan dalam dimensi daya tanggap yang menjadi sumber ketidakpuasan penumpang adalah kurangnya pemberian informasi yang jelas, benar dan tepat dari petugas kereta api baik di stasiun maupun di dalam gerbong kepada penumpang mengenai jadwal pemberangkatan, perubahan maupun masalah yang terkait dengan perjalanan kereta api. Yang terakhir dimensi yang dirasakan tidak puas adalah dimensi bukti fisik. Hal ini bisa terlihat kereta api yang selama ini beroperasi bukan kereta baru melainkan kereta bekas pakai negara Jepang yang diperbaiki oleh pengelola kereta api. 


\section{Pemilihan transportasi publik}

Dalam memilih transportasi umum yang akan digunakan, para penumpang tidak terlepas dari beberapa pertimbangan, salah satunya adalah relasi dengan penumpang lainnya. Teori ini disebut teori proxemics. Gagasan utama dari teori proxemics adalah bahwa relasi sosial antar individu memiliki pengaruh terhadap bagaimana individu mengatur jarak fisik di antara mereka. Teori ini dikemukakan oleh Hall (1966) yang melakukan observasi terhadap perilaku individu dalam suatu ruang sosial.

Pada penelitian yang dilakukan Ilyas (2018) dijelaskan pemilihan moda transportasi pada penglaju Jabodetabek berdasarkan teori proxemics. Pada responden perempuan, faktor yang paling dipertimbangkan masih menunjukkan persentase terbesar pada waktu tempuh, akan tetapi, responden laki-laki menunjukkan persentase lebih besar pada kenyamanan pribadi. Hal menarik yang ditemukan dalam data adalah bahwa proxemics behaviour responden pada umumnya lebih terbuka pada orang lain berjenis kelamin perempuan, dan lebih tertutup pada laki-laki. Sementara itu, rata-rata proxemics behaviour yang paling tertutup adalah antara responden perempuan dengan orang lain berjenis kelamin laki-laki. Ini menunjukkan bahwa jenis kelamin orang lain menjadi signifikan dalam proxemics behaviour responden, di mana responden perempuan cenderung lebih tertutup terhadap orang lain berjenis kelamin laki-laki, sementara responden laki-laki cenderung lebih terbuka terhadap orang lain berjenis kelamin perempuan.

\section{Kepuasaan pengguna transportasi publik}

Ada beberapa hal yang menjadi indikator dari kepuasaan pelanggan. Pagano dan McKnight dalam Masri (2002), mengembangkan pengukuran kepuasan pelanggan yang sering digunakan pada jasa transportasi, meliputi delapan aspek pelayanan zmasing-masing dipercayai mewakili kebutuhan dasar dari keseluruhandimensi kualitas, yaitu:

\section{Keandalan dan Kinerja Tepat Waktu (Reliability and On-TimePerformance)}

Pengumuman penundaan/pembatalan keberangkatan (notification of delays and cancellations) waktu tunggu (wait times), alasan kedatangan yang tepat waktu (reasonably on-time arrivals), minimal penundaan atas kendaraan (minimal onvehicle delays).

\section{Kenyamanan (Comfort)}

Adanya jaminan (guaranteed space), kondisi dan kebersihan kendaraan (condition and cleanliness of vehicles), kemulusan perjalanan (smoothness of ride), ventilasi dan penyejuk udara (air conditioning and ventilation), tempat berlindung (shelter)dan tempat duduk untuk menunggu di luar ruang.

\section{Kemudahan Membuat Reservasi}

Accomodation to changes, yaitu akomodasi untuk melakukan perubahan, memungkinkan pengguna untuk menentukan menyusun waktu penjemputan (preset pick-up times), memilih pengendara (rider determined), mempersingkat waktu reservasi (shortness of reservation time) dan prosedur reservasi yang mudah dan tidak berbelit-belit (easy of procedure).

\section{Perluasan Layanan (Extend of Service)}

Layanan total 24 jam (total hour of availability); pembatasan jarak (distance restriction); layanan akhir minggu dan sore hari (weekend and evening service); penolakan perjalanan yang rendah disebabkan pembatasan kapasitas (low rate of trips denial due to capacity constraint).

\section{Akses Kendaraan (Vehicles Access)}

Jarak lorong antar tempat duduk dalam gerbong kereta (aisle width), tinggi pijakan kaki saat masuk ke dalam gerbong (first step height), jumlah tangga masuk (number of steps), bantuan bagasi (assistance with packages), dan tingkat bantuan saat dalam kendaraan hingga ke tujuan (level of assistance provided from vehicles to destination).

6. Keamanan (Safety)

Resiko kemungkinan terjadi kekerasan dan kecelakaan rendah (low probability of assault or accidental injury), lintasan kereta api yang aman, jalur rel kereta api yang aman dan masinis yang mengutamakan keamanan.

\section{Karakteristik Masinis Dan Kru (Driver \&Crew Characteristic)}

Kemampuan menangani medis dalam keadaan darurat (ability to handle medical emergencies), jujur dan ramah (courteous and friendly), sensitif dan memahami kebutuhan penumpang KA (sensitive and knowledgeable about riders need), sensitive pada kebutuhan individual, tingkat profesionalisme dan berpengalaman. 


\section{Tanggung Jawab Pada Individual (Responsiveness to Individual)}

Operator atau customer service yang ramah dan responsif, memberikan informasi yang jelas, mengikuti prosedur, bertanggung jawab pada keluhan dan pemberian saran.

\section{METODE PENELITIAN}

Penelitian yang penulis lakukan kali ini termasuk ke dalam penelitian sosial dan akan menggunakan metode angket. Menurut Umar (2003) teknik angket (kuesioner) merupakan suatu pengumpulan data dengan memberikan atau menyebarkan daftar pertanyaan atau pernyataan kepada responden dengan dengan harapan memberikan respon atas daftar pertanyaan tersebut. Pertanyaan pada penelitian kondisi esksisting sarana dan prasarna KRL Commuter Line mencakup layanan petugas dalam gerbong wanita, perilaku penumpang di gerbong khusus wanita, sistem informasi di dalam gerbong, kapasitas rangkaian pada jam sibuk dan kapasitas gerbong pada jam sibuk. Bagian selanjutnya pada kuesioner adalah pemilihan tingkat kepentingan upaya untuk meningkatkan kualitas mobilitas wanita pengguna KRL dengan 4 pilihan yaitu: penambahan tempat duduk prioritas, penambahan gerbong khusus wanita, penambahan frekuensi datangnya kereta, dan penambahan jumlah petugas.

Pada bagian ini, kuesioner disusun dengan menggunakan metode Analytical Hierarchy Process (AHP). Metode AHP adalah suatu metode pengolahan data yang dikembangkan oleh Saaty pada tahun 1993. Metode ini menguraikan masalah yang terdiri lebih dari satu faktor dan bersifat rumit hingga pada akhirnya menjadi sebuah tingkatan. Pemberian nilai dapat dilihat pada Tabel 1

Untuk bagian kondisi eksisting sarana dan prasarana KRL Commuter Line dijawab responden menggunakan skala likert. Nilai-nilai tersebut didefinisikan sebagai berikut angka 1 hampir tidak tersedia, angka 2 kurang tersedia, angka 3 tersedia, dan angka 4 sangat tersedia seperti yang terdapat pada Tabel 2. Hal ini dilakukan untuk mempermudah hasil analisis. Penelitian yang dilakukan akan menggunakan metode One Sample T-Test. Persepsi pembaca adalah semakin tinggi sebuah angka maka menunjukan sesuatu yang semakin positif. Penelitian ini mengambil nilai tes sebesar 2,5 (peralihan dari kondisi kurang tersedia ke tersedia) pada selisih rataan.

Tabel 1. Penilaian tingkat kepentingan upaya perbaikan sarana pada transportasi umum (KRL) pada kuesioner

\begin{tabular}{cc}
\hline Nilai & Definisi \\
\hline 1 & Variabel disebelah kiri mutlak lebih penting \\
2 & Variabel disebelah kiri sangat lebih penting \\
3 & Variabel disebelah kiri lebih penting \\
4 & Variabel disebelah kiri sedikit lebih penting \\
5 & Kedua variabel sama penting \\
6 & Variabel disebelah kanan sedikit lebih penting \\
7 & Variabel disebelah kanan lebih penting \\
8 & Variabel disebelah kanan sangat lebih penting \\
9 & Variabel disebelah kanan mutlak lebih penting \\
\hline
\end{tabular}

Perbedaan skala pemberian nilai pada Tabel 1 dalam pemberian nilai pertanyaan yang menggunakan metode AHP disebabkan karena keterbatasan skala linear pada google form. Untuk itu penulis mengubah skala pemberian nilai yang seharusnya berjumlah 17, menjadi berjumlah 9 dengan menghilangkan penilaian antara dua pilihan berupa angka 2,4,6,8. Secara matematis, hal ini tentunya berpengaruh terhadap ketelitian angka yang dihasilkan, tetapi tidak berpengaruh pada hasil akhir penelitian ini. 
Tabel 2. Penilaian tingkat ketersediaan sarana, prasarana pada transportasi umum (KRL) pada kuesioner

\begin{tabular}{cc}
\hline Nilai & Definisi \\
\hline 1 & Hampir Tidak Tersedia \\
2 & Kurang Tersedia \\
3 & Tersedia \\
4 & Sangat Tersedia \\
\hline
\end{tabular}

\section{HASIL DAN PEMBAHASAN}

Responden yang berpartisipasi dalam penelitian ini berjumlah 100 orang yang terbagi menjadi 52 wanita dan 48 lakilaki. Data-data umum yang diperoleh dalam penelitian ini meliputi jenis kelamin responden, usia responden, domisili responden, pendidikan terakhir responden, pekerjaan responden, stasiun asal dan tujuan responden. Data umum tersebut akan disajikan pada Tabel 3 hingga Tabel 8 berikut. Kolom Tipe pada tabel merupakan jenis kelamin responden yang dibedakan menjadi 2 tipe, yaitu Laki-laki (L) dan Wanita (W).

Tabel 3. Usia responden

\begin{tabular}{ccccccccc}
\hline \multirow{2}{*}{ No } & \multirow{2}{*}{ Tipe } & \multirow{2}{*}{ Jumlah } & \multicolumn{6}{c}{ Rentang Usia Responden (tahun) } \\
\cline { 4 - 9 } & & & $15-20$ & $21-30$ & $31-40$ & $41-50$ & $51-60$ & $61-70$ \\
\hline 1 & L & 48 & 5 & 25 & 5 & 3 & 7 & 3 \\
2 & W & 52 & 3 & 21 & 16 & 5 & 6 & 1 \\
\hline
\end{tabular}

Tabel 4. Pendidikan terakhir responden

\begin{tabular}{cccccccc}
\hline \multirow{2}{*}{ No } & \multirow{2}{*}{ Tipe } & \multirow{2}{*}{ Jumlah } & \multicolumn{5}{c}{ Pendidikan Terakhir Responden } \\
\cline { 4 - 8 } & & & SD/SMP & SMA & Diploma & S1 & S2/S3 \\
\hline 1 & L & 48 & 1 & 29 & 0 & 12 & 6 \\
2 & W & 52 & 2 & 17 & 5 & 24 & 4 \\
\hline
\end{tabular}

Tabel 5. Pekerjaan responden

\begin{tabular}{ccccccc}
\hline \multirow{2}{*}{ No } & \multirow{2}{*}{ Tipe } & \multirow{2}{*}{ Jumlah } & \multicolumn{5}{c}{ Pekerjaan Responden } \\
\cline { 4 - 7 } & & & Pelajar/ Mahasiswa & Staff/Karyawan & Manajer & Lainnya \\
\hline 1 & L & 48 & 25 & 10 & 6 & 7 \\
2 & W & 52 & 13 & 34 & 2 & 3 \\
\hline
\end{tabular}

Tabel 6. Domisili responden

\begin{tabular}{cccccccc}
\hline \multirow{2}{*}{ No } & \multirow{2}{*}{ Tipe } & Jumlah & \multicolumn{5}{c}{ Domisili Responden } \\
\cline { 4 - 7 } & & & Jakarta & Bogor & Depok & Tangerang & Bekasi \\
\hline 1 & L & 48 & 22 & 2 & 7 & 14 & 3 \\
2 & W & 52 & 20 & 5 & 8 & 11 & 8 \\
\hline
\end{tabular}

Data umum berikutnya yang diperoleh dari jawaban kuesioner adalah stasiun asal dan stasiun tujuan para responden. Stasiun akan dibedakan menjadi 2 yaitu stasiun tengah kota (Stasiun Duri, Stasiun Tanah Abang, Stasiun Jakarta Kota, Stasiun Manggarai, Stasiun Jatinegara dan Stasiun Kampung Bandan) dan stasiun pinggir kota yang sudah tidak termasuk dalam Kota Jakarta. 
Tabel 7. Stasiun tujuan responden

\begin{tabular}{ccccc}
\hline \multirow{2}{*}{ No } & \multirow{2}{*}{ Tipe } & \multirow{2}{*}{ Jumlah } & - & \multicolumn{2}{c}{ Stasiun Tujuan Responden } \\
\cline { 3 - 5 } & L & 48 & Tengah Kota & Pinggir Kota \\
\hline 2 & W & 52 & 45 & 13 \\
\hline
\end{tabular}

Tabel 8. Stasiun asal responden

\begin{tabular}{ccccc}
\hline \multirow{2}{*}{ No } & \multirow{2}{*}{ Tipe } & \multirow{2}{*}{ Jumlah } & - & \multicolumn{2}{c}{ Stasiun Asal Responden } \\
& & & Tengah Kota & Pinggir Kota \\
\hline 1 & L & 48 & 20 & 28 \\
2 & W & 52 & 16 & 36 \\
\hline
\end{tabular}

Rangkuman hasil jawaban mengenai kondisi eksisting akan disajikan dengan bentuk tabel untuk semua bagian. Tabel tersebut terdiri atas variabel jenis kelamin responden jumlah responden, nilai minimum, nilai maksimum, dan nilai mean. Data hasil survei dapat dilihat mulai Tabel 9 sampai Tabel 13.

Pada Tabel 9 jenis variabel pertanyaan ini ditujukan khusus untuk responden wanita. Dapat dilihat bahwa layanan yang diberikan oleh petugas KRL Commuter Line sudah cukup baik dan memuaskan. Hal ini dapat dilihat dari nilai mean yang berada diatas dari nilai tengah yaitu 2,5. Pada variabel petugas menegur apabila terdapat laki-laki di gerbong khusus wanita para responden memberikan jawaban minimum dengan nilai 3 (setuju) artinya gerbong khusus wantita terbebas dari penumpang laki-laki.

Pada Tabel 10 jenis variabel pertanyaan tersebut hanya ditanyakan kepada responden wanita. Hasilnya menyatakan bahwa tindak kekerasan fisik terjadi dibawah nilai 2,5 tetapi nilai mean tindakan adu mulut nilai masih sedikit di atas 2,5. Penumpang masih bersikap tidak tertib saat masuk dan berada di dalam gerbong, tetapi hasilnya menyatakan bahwa penumpang merasa cukup aman dan nyaman dalam gerbong khusus wanita.

Tabel 9. Layanan petugas di gerbong wanita

\begin{tabular}{|c|c|c|c|c|c|c|}
\hline No & Variabel & Tipe & $\mathrm{N}$ & Minimum & Maksimum & Rataan \\
\hline 1 & $\begin{array}{l}\text { Petugas menegur apabila terdapat laki-laki di } \\
\text { gerbong khusus wanita }\end{array}$ & W & 52 & 3 & 4 & 3,81 \\
\hline 2 & $\begin{array}{c}\text { Gerbong khusus wanita bebas dari tindakan } \\
\text { kriminalitas }\end{array}$ & W & 52 & 1 & 4 & 2,58 \\
\hline 3 & $\begin{array}{c}\text { Gerbong khusus wanita bebas dari pelecehan } \\
\text { (verbal dan seksual) }\end{array}$ & $\mathrm{W}$ & 52 & 2 & 4 & 3,23 \\
\hline 4 & $\begin{array}{c}\text { Kondisi kebersihan gerbong khusus wanita } \\
\text { memadai }\end{array}$ & $\mathrm{W}$ & 52 & 1 & 4 & 3,25 \\
\hline
\end{tabular}

Tabel 10. Perilaku penumpang wanita dalam gerbong

\begin{tabular}{|c|c|c|c|c|c|c|}
\hline No & Variabel & Tipe & $\mathrm{N}$ & Minimum & Maksimum & Mean \\
\hline 1 & $\begin{array}{l}\text { Tidak terjadi adu mulut antar penumpang untuk } \\
\text { mendapat tempat duduk }\end{array}$ & $\mathrm{W}$ & 52 & 1 & 4 & 2,44 \\
\hline 2 & Tidak terjadi kekerasan fisik antar penumpang & $\mathrm{W}$ & 52 & 1 & 4 & 2,83 \\
\hline 3 & $\begin{array}{l}\text { Penumpang merasa aman dan nyaman dalam } \\
\text { gerbong khusus wanita }\end{array}$ & $\mathrm{W}$ & 52 & 1 & 4 & 3,12 \\
\hline 4 & $\begin{array}{l}\text { Penumpang tertib saat masuk dan berada di dalam } \\
\text { gerbong }\end{array}$ & $\mathrm{W}$ & 52 & 1 & 4 & 2,04 \\
\hline
\end{tabular}

Tabel 11 menyatakan bahwa seluruh variabel mengenai sistem informasi dalam gerbong sudah cukup memuaskan dengan angka mean berada diatas nilai 2,5. Penumpang wanita memberikan nilai minimum 3 untuk variabel pemberitahuan rute kereta saat berada di dalam gerbong. 
Pada Tabel 12 dapat dilihat bahwa para responden menilai bahwa rangkaian kereta selalu terisi penuh saat jam sibuk, antrian di stasiun menjadi panjang, dan penumpang harus saling berdesak-desakan selama berada dalam kereta. Namun pada variabel waktu kedatangan kereta, rata-rata penumpang laki-laki berada di angka 2,44 sedangkan responden wanita nilainya 2,52 .

Pada Tabel 13 diperoleh data jawaban responden bahwa gerbong khusus wanita terisi penuh pada saat jam sibuk dan tempat duduk dalam gerbong tidak cukup untuk menampung seluruh penumpang. Tempat duduk prioritas baik di gerbong umum maupun khusus mendapat nilai diatas 2,5. Kedua jenis responden setuju bahwa penumpang wanita lebih mudah mendapat tempat duduk di gerbong umum.

Tabel 11. Sistem informasi dalam gerbong

\begin{tabular}{|c|c|c|c|c|c|c|}
\hline No & Variabel & Tipe & $\mathrm{N}$ & Minimum & Maksimum & Mean \\
\hline \multirow{2}{*}{1} & \multirow{2}{*}{$\begin{array}{c}\text { Kedatangan kereta api terjadwal dan } \\
\text { tepat waktu }\end{array}$} & $\mathrm{L}$ & 48 & 2 & 4 & 3,38 \\
\hline & & W & 52 & 1 & 4 & 3,02 \\
\hline \multirow{2}{*}{2} & \multirow{2}{*}{$\begin{array}{l}\text { Dalam gerbong terdapat pemberitahuan } \\
\text { rute kereta }\end{array}$} & $\mathrm{L}$ & 48 & 1 & 4 & 3,52 \\
\hline & & W & 52 & 3 & 4 & 3,60 \\
\hline \multirow{2}{*}{3} & \multirow{2}{*}{$\begin{array}{l}\text { Dalam gerbong terdapat pemberitahuan } \\
\text { setiap tiba di stasiun pemberhetian }\end{array}$} & $\mathrm{L}$ & 48 & 1 & 4 & 3,65 \\
\hline & & $\mathrm{W}$ & 52 & 2 & 4 & 3,67 \\
\hline \multirow{2}{*}{4} & \multirow{2}{*}{$\begin{array}{l}\text { Dalam gerbong terdapat tanda yang } \\
\text { membedakan gerbong khusus }\end{array}$} & $\mathrm{L}$ & 48 & 1 & 4 & 3,40 \\
\hline & & $\mathrm{W}$ & 52 & 1 & 4 & 3,62 \\
\hline \multirow{2}{*}{5} & \multirow{2}{*}{$\begin{array}{l}\text { Dalam gerbong terdapat pegumuman } \\
\text { tentang larangan selama berada dalam } \\
\text { gerbong }\end{array}$} & $\mathrm{L}$ & 48 & 1 & 1 & 3,42 \\
\hline & & $\mathrm{W}$ & 52 & 1 & 4 & 3.63 \\
\hline
\end{tabular}

Tabel 12. Kapasitas tiap rangkaian pada jam sibuk

\begin{tabular}{ccccccc}
\hline No & Variabel & Tipe & N & Minimum & Maksimum & Mean \\
\hline \multirow{2}{*}{ I } & $\begin{array}{c}\text { Seluruh rangkaian kereta tidak selalu } \\
\text { terisi penuh pada jam sibuk }\end{array}$ & L & 48 & 1 & 4 & 1,52 \\
& W & 52 & 1 & 4 & 1,35 \\
\hline \multirow{2}{*}{2} & $\begin{array}{c}\text { Antrian di stasiun tidak menjadi panjang } \\
\text { pada jam sibuk saat menunggu kereta } \\
\text { datang }\end{array}$ & L & 48 & 1 & 4 & 1,62 \\
& W & 52 & 1 & 4 & 1,56 \\
3 & $\begin{array}{c}\text { Penumpang tidak harus berdesak- } \\
\text { desakan untuk naik dan selama berada } \\
\text { dalam kereta }\end{array}$ & L & 48 & 1 & 4 & 1,75 \\
& W & 52 & 1 & 4 & 1,60 \\
4 & Waktu kedatangan kereta tidak & L & 48 & 1 & 4 & 2,56 \\
& membutuhkan waktu yang lama & W & 52 & 1 & 2,48 \\
\hline
\end{tabular}

Tabel 13. Kapasitas tiap gerbong pada jam sibuk

\begin{tabular}{|c|c|c|c|c|c|c|}
\hline No & Variabel & Tipe & $\mathrm{N}$ & Minimum & Maksimum & Rataan \\
\hline \multirow{2}{*}{1} & \multirow{2}{*}{$\begin{array}{l}\text { Gerbong khusus wanita terisi penuh pada saat } \\
\text { jam sibuk }\end{array}$} & $\mathrm{L}$ & 48 & 1 & 4 & 1.62 \\
\hline & & W & 52 & 1 & 4 & 1.32 \\
\hline \multirow{2}{*}{2} & \multirow{2}{*}{$\begin{array}{l}\text { Tempat duduk dalam gerbong cukup } \\
\text { menampung seluruh penumpang }\end{array}$} & $\mathrm{L}$ & 48 & 1 & 4 & 2.00 \\
\hline & & $\mathrm{W}$ & 52 & 1 & 4 & 1.83 \\
\hline \multirow{2}{*}{3} & \multirow{2}{*}{$\begin{array}{l}\text { Tempat duduk prioritas digunakan sesuai } \\
\text { fungsinya di gerbong umum }\end{array}$} & $\mathrm{L}$ & 48 & 1 & 4 & 2.79 \\
\hline & & W & 52 & 1 & 4 & 2.69 \\
\hline
\end{tabular}


Tabel 13. Kapasitas tiap gerbong pada jam sibuk (lanjutan)

\begin{tabular}{ccccccc}
\hline No & Variabel & Tipe & $\mathrm{N}$ & Minimum & Maksimum & Rataan \\
\hline \multirow{2}{*}{4} & Tempat duduk prioritas digunakan sesuai & $\mathrm{L}$ & 48 & 1 & 4 & 2.81 \\
& fungsinya di gerbong khusus & $\mathrm{W}$ & 52 & 1 & 4 & 2.90 \\
\hline \multirow{2}{*}{5} & $\begin{array}{c}\text { Penumpang wanita lebih mudah mendapat } \\
\text { tempat duduk di gerbong umum }\end{array}$ & $\mathrm{L}$ & 48 & 1 & 1 & 2.90 \\
& W & 52 & 1 & 4 & 2.60 \\
\hline
\end{tabular}

Berikut akan disajikan rangkuman hasil jawaban para responden pengguna KRL Commuter Line mengenai tingkat kepentingan upaya yang dapat dilakukan untuk meningkatkan fasilitas gerbong khusus wanita dengan menggunakan angka. Jawaban dapat dilihat dalam Tabel 14.

Tabel 14. Upaya meningkatkan fasilitas gerbong khusus wanita

\begin{tabular}{|c|c|c|c|c|c|c|c|c|c|c|c|c|}
\hline \multirow{3}{*}{ No } & \multirow{3}{*}{ Pertanyaan } & \multirow{3}{*}{ Tipe } & \multirow{3}{*}{$\mathrm{N}$} & \multicolumn{9}{|c|}{ Vilai } \\
\hline & & & & 1 & 2 & 3 & 4 & 5 & 6 & 7 & 8 & 9 \\
\hline & & & & -9 & -7 & -5 & - & 1 & 3 & 5 & 7 & 9 \\
\hline \multirow{2}{*}{1} & $\begin{array}{l}\text { Menurut Anda manakah yang lebih penting antara } \\
\text { Penambahan Tempat Duduk Prioritas }\end{array}$ & $\mathrm{L}$ & 48 & 3 & 7 & 6 & 4 & 4 & 5 & 6 & 7 & 6 \\
\hline & $\begin{array}{l}\text { dibandingkan dengan Penambahan Gerbong } \\
\text { Khusus Wanita? }\end{array}$ & W & 52 & 0 & 3 & 3 & 0 & 6 & 2 & 14 & 5 & 19 \\
\hline \multirow{2}{*}{2} & $\begin{array}{l}\text { Menurut Anda manakah yang lebih penting antara } \\
\text { Penambahan Tempat Duduk Prioritas }\end{array}$ & $\mathrm{L}$ & 48 & 1 & 1 & 0 & 2 & 5 & 0 & 10 & 14 & 15 \\
\hline & $\begin{array}{l}\text { dibandingkan dengan Penambahan frekuensi } \\
\text { datangnya kereta? }\end{array}$ & W & 52 & 1 & 1 & 1 & 0 & 1 & 1 & 12 & 12 & 23 \\
\hline \multirow[t]{2}{*}{3} & $\begin{array}{l}\text { Menurut Anda manakah yang lebih penting antara } \\
\text { Penambahan Tempat Duduk Prioritas }\end{array}$ & $\mathrm{L}$ & 48 & 9 & 12 & 7 & 9 & 6 & 3 & 1 & 1 & 0 \\
\hline & $\begin{array}{l}\text { dibandingkan dengan Penambahan Jumlah } \\
\text { Petugas? }\end{array}$ & $\mathrm{W}$ & 52 & 8 & 7 & 12 & 4 & 5 & 2 & 7 & 2 & 5 \\
\hline \multirow{2}{*}{4} & $\begin{array}{l}\text { Menurut Anda manakah yang lebih penting antara } \\
\text { Penambahan Gerbong Khusus Wanita }\end{array}$ & $\mathrm{L}$ & 48 & 3 & 1 & 1 & 1 & 7 & 3 & 5 & 10 & 17 \\
\hline & $\begin{array}{l}\text { dibandingkan dengan Penambahan frekuensi } \\
\text { datangya kereta? }\end{array}$ & W & 52 & 1 & 3 & 2 & 0 & 4 & 2 & 11 & 11 & 18 \\
\hline \multirow{2}{*}{5} & $\begin{array}{l}\text { Menurut Anda manakah yang lebih penting antara } \\
\text { Penambahan Gerbong Khusus Wanita }\end{array}$ & $\mathrm{L}$ & 48 & 6 & 8 & 13 & 8 & 7 & 1 & 2 & 0 & 3 \\
\hline & $\begin{array}{l}\text { dibandingkan dengan Penambahan Jumlah } \\
\text { Petugas? }\end{array}$ & W & 52 & 13 & 7 & 10 & 5 & 6 & 2 & 4 & 2 & 3 \\
\hline \multirow{2}{*}{6} & $\begin{array}{l}\text { Menurut Anda manakah yang lebih penting antara } \\
\text { Penambahan frekuensi datangya kereta }\end{array}$ & $\mathrm{L}$ & 48 & 20 & 9 & 10 & 4 & 2 & 0 & 3 & 0 & 0 \\
\hline & $\begin{array}{l}\text { dibandingkan dengan Penambahan Jumlah } \\
\text { Petugas? }\end{array}$ & W & 52 & 27 & 14 & 6 & 1 & 0 & 1 & 3 & 0 & 0 \\
\hline
\end{tabular}

Berdasarkan Tabel 14 dapat dilihat bahwa jawaban yang diberikan oleh para responden memiliki sebaran yang cukup merata. Pilihan upaya untuk menambah frekuensi datangnya kereta menjadi pilihan yang cukup penting bagi para responden dilihat dari nilai yang diberikan saat variabel ini dibandingkan dengan variabel lain. Banyak responden yang memberikan angka 1 atau 9 untuk variabel ini yang berarti mutlak lebih penting. Sedangkan variabel yang dianggap kurang penting adalah penambahan jumlah petugas karena nilai yang diberikan cukup rendah saat dibandingkan dengan variabel lainnya.

Analisis yang dilakukan pada bagian ini bertujuan untuk mengetahui kondisi eksisting yang dirasakan pengguna saat bertransportasi menggunakan KRL Commuter Line Jabodetabek. Analisis dilakukan dengan menggunakan metode penelitian One Sample T-Test dengan bantuan software SPSS. Kelompok variabel yang diuji dibagi menjadi 3 kelompok besar yaitu sistem informasi saat berada di dalam gerbong, kapasitas tiap rangkaian, dan kapasitas tiap gerbong KRL Commuter Line. Khusus untuk responden wanita terdapat tambahan 2 kelompok variabel yang diuji yaitu layanan petugas dalam gerbong khusus wanita dan perilaku penumpang wanita saat berada di dalam gerbong. Setelah mendapatkan seluruh hasil kuesioner dari responden, selanjutnya dilakukan uji validitas dan reliabilitas. Pengujian ini mengambil sampel acak sebanyak 10 responden. 
Pada kelompok variabel layanan petugas di gerbong khusus wanita dapat dilihat untuk hasil uji validitas terdapat satu variabel yang tidak valid, yaitu variabel petugas menegur apabila terdapat laki-laki di gerbong khusus wanita. Maka dari itu, untuk pengujian selanjutnya yaitu uji reabilitas dan uji One Sample T Test variabel tersebut tidak akan diikutsertakan dan akan dihilangkan. Variabel yang sudah dinyatakan valid kemudian melakukan uji reabilitas. Uji reabilitas bertujuan untuk mengetahui apakah suatu variabel reliabel dan konsisten. Proses uji reabilitas menggunakan software SPSS dengan metode Alpha Conbrach's. Suatu variabel dikatakan reliabel dan memenuhi syarat apabila nilai Alpha Conbrach's lebih dari 0.6, dan dinyatakan sangat bagus apabila nilainya lebih besar dari 0.9. Seluruh variabel yang diuji terbukti realiabel dan dilanjutkan menuju uji one sample t test.

Pada Tabel 15 diperoleh hasil uji One Sample T Test yang nilai rataan variabel nomor 2 dan 3 berada jauh diatas angka 2,5, yang berarti para responden menilai bahwa kondisi eksisting gerbong khusus wanita bebas dari pelecehan (verbal dan seksual) dan kondisi kebersihan gerbong khusus wanita memadai. Kedua variabel ini memiliki nilai $\alpha$ yang signifikan terhadap 0,05. Sedangkan untuk variabel gerbong khusus wanita bebas dari tindakan kriminalitas memiliki nilai rataan 2,58 yang nilai $\alpha$ nya tidak signifikan terhadap 0,05 .

Pada Tabel 16 dapat dilihat untuk variabel nomor 2 memiliki nilai rataan diatas 2,83 dan nilai $\alpha$ signifikan terhadap 0,05 , yang berarti dalam gerbong khusus wanita tidak terjadi kekerasan fisik antar penumpang. Begitu pula dengan variabel nomor 3 memiliki nilai rataan jauh diatas 2,5 dan nilai $\alpha$ signifikan terhadap 2,5 yang berarti para penumpang merasa aman dan nyaman berada dalam gerbong khusus wanita. Sedangkan variabel nomor 1 memiliki nilai rataan dibawah 2,44 walaupun nilai $\alpha$ tidak signifikan terhadap 0,05 yang berarti masih terjadi adu mulut antar penumpang untuk mendapatkan tempat duduk. Variabel nomor 4 memiliki nilai rataan jauh dibawah 2,5 dan nilai $\alpha$ yang siginfikan terhadap 0,05 . Hal ini berarti para responden menyatakan bahwa penumpang tidak tertib saat masuk dan berada di dalam gerbong.

Pada Tabel 17 diperoleh hasil untuk semua variabel memiliki nilai rataan jauh diatas 2,5 dan nilai $\alpha$ yang signifikan terhadap 0,05 baik untuk responden laki-laki maupun responden wanita. Hal ini berarti kondisi eksisting untuk variabel kedatangan kereta api terjadwal dan tepat waktu, variabel dalam gerbong terdapat pemberitahuan rute kereta, variabel dalam gerbong terdapat tanda yang membedakan antar gerbomg, dan variabel dalam gerbong terdapat pengumuman tentang larangan selama berada dalam gerbong sudah cukup baik dan tersedia.

Pada Tabel 18 diperoleh hasil untuk variabel nomor 1, nomor 2, nomor 3 baik untuk responden laki-laki maupun responden wanita memiliki nilai rataan jauh dibawah 2,5 dan nilai $\alpha$ signifikan terhadap 0,05 . Hal ini berarti kondisi eksisting yang terjai adalah seluruh rangkaian kereta terisi penuh pada jam sibuk, antrian di stasiun menjadi panjang pada jam sibuk saat menunggu kedatangan kereta, penumpang harus berdesak-desakan untuk naik dan selama berada dalam kereta. Namun, untuk variabel nomor 4 kelompok responden laki-laki memiliki nilai rataan sedikit diatas 2,5 dan kelompok responden wanita dibawah 2,5 walaupun nilai $\alpha$ tidak signifikan terhadap 0,05. Hal ini berarti waktu kedatangan kereta tidak memerlukan waktu yang lama menurut responden laki-laki dan kebalikannya untuk responden wanita.

Tabel 15. Kondisi eksisting layanan petugas di gerbong khusus wanita

\begin{tabular}{cccccccc}
\hline No & Variabel & Tipe & $\mathrm{N}$ & Rataan & $\begin{array}{c}\text { Selisih } \\
\text { Rataan }\end{array}$ & $\alpha$ & $\begin{array}{c}\alpha \leq 0,05 \\
\text { (Ya/Tidak) }\end{array}$ \\
\hline 1 & $\begin{array}{c}\text { Gerbong khusus wanita bebas } \\
\text { dari tindakan kriminalitas }\end{array}$ & $\mathrm{W}$ & 52 & 2,58 & 0.077 & 0,556 & Tidak \\
\hline 2 & $\begin{array}{c}\text { Gerbong khusus wanita bebas } \\
\text { dari pelecehan (verbal dan } \\
\text { seksual) }\end{array}$ & $\mathrm{W}$ & 52 & 3,23 & 0,731 & $<0,001$ & Ya \\
\hline 3 & $\begin{array}{c}\text { Kondisi kebersihan gerbong } \\
\text { khusus wanita memadai }\end{array}$ & $\mathrm{W}$ & 52 & 3,25 & 0,750 & $<0,001$ & Ya \\
\hline
\end{tabular}


Tabel 16. Kondisi eksisting perilaku penumpang di gerbong khusus wanita

\begin{tabular}{cccccccc}
\hline No & Variabel & Tipe & N & Rataan & $\begin{array}{c}\text { Selisih } \\
\text { Rataan }\end{array}$ & $\alpha$ & $\begin{array}{c}\alpha \leq 0,05 \\
\text { (Ya/Tidak) }\end{array}$ \\
\hline 1 & $\begin{array}{c}\text { Tidak terjadi adu mulut antar } \\
\text { penumpang untuk mendapat } \\
\text { tempat duduk }\end{array}$ & W & 52 & 2,44 & $-0,058$ & 0,709 & Tidak \\
\hline 2 & $\begin{array}{c}\text { Tidak terjadi kekerasan fisik } \\
\text { antar penumpang }\end{array}$ & W & 52 & 2,83 & 0,327 & $<0,001$ & Ya \\
\hline 3 & $\begin{array}{c}\text { Penumpang merasa aman dan } \\
\text { nyaman dalam gerbong } \\
\text { khusus wanita }\end{array}$ & W & 52 & 3,12 & 0,615 & 0,001 & Ya \\
\hline 4 & $\begin{array}{c}\text { Penumpang tertib saat masuk } \\
\text { dan berada di dalam gerbong }\end{array}$ & W & 52 & 2,04 & $-0,462$ & 0,330 & Tidak \\
\hline
\end{tabular}

Tabel 17. Kondisi eksisting sistem informasi dalam gerbong

\begin{tabular}{|c|c|c|c|c|c|c|c|}
\hline No & Variabel & Tipe & $\mathrm{N}$ & Rataan & $\begin{array}{l}\text { Selisih } \\
\text { Rataan }\end{array}$ & $\alpha$ & $\begin{array}{c}\alpha \leq 0,05 \\
(\mathrm{Ya} / \text { Tidak })\end{array}$ \\
\hline \multirow{2}{*}{1} & \multirow{2}{*}{$\begin{array}{l}\text { Kedatangan kereta api } \\
\text { terjadwal dan tepat waktu }\end{array}$} & $\mathrm{L}$ & 48 & 3,38 & 0,875 & $<0,001$ & Ya \\
\hline & & W & 52 & 3,02 & 0,519 & $<0,001$ & $\mathrm{Ya}$ \\
\hline \multirow{2}{*}{2} & \multirow{2}{*}{$\begin{array}{l}\text { Dalam gerbong terdapat } \\
\text { pemberitahuan rute kereta }\end{array}$} & $\mathrm{L}$ & 48 & 3,52 & 1,021 & $<0,001$ & $\mathrm{Ya}$ \\
\hline & & $\mathrm{W}$ & 52 & 3,60 & 1,096 & $<0,001$ & $\mathrm{Ya}$ \\
\hline \multirow[b]{2}{*}{3} & \multirow{2}{*}{$\begin{array}{l}\text { Dalam gerbong terdapat } \\
\text { pemberitahuan setiap tiba di } \\
\text { stasiun pemberhetian }\end{array}$} & $\mathrm{L}$ & 48 & 3,65 & 1,146 & $<0,001$ & $\mathrm{Ya}$ \\
\hline & & $\mathrm{W}$ & 52 & 3,67 & 1,173 & 0,000 & $\mathrm{Ya}$ \\
\hline \multirow[b]{2}{*}{4} & \multirow{2}{*}{$\begin{array}{c}\text { Dalam gerbong terdapat tanda } \\
\text { yang membedakan gerbong } \\
\text { khusus }\end{array}$} & $\mathrm{L}$ & 48 & 3,40 & 0,896 & $<0,001$ & $\mathrm{Ya}$ \\
\hline & & W & 52 & 3,62 & 1,115 & $<0,001$ & $\mathrm{Ya}$ \\
\hline \multirow[b]{2}{*}{5} & \multirow{2}{*}{$\begin{array}{c}\text { Dalam gerbong terdapat } \\
\text { pegumuman tentang larangan } \\
\text { selama berada dalam gerbong }\end{array}$} & $\mathrm{L}$ & 48 & 3,42 & 0,917 & $<0,001$ & $\mathrm{Ya}$ \\
\hline & & W & 52 & 3,63 & 1,135 & $<0,001$ & $\mathrm{Ya}$ \\
\hline
\end{tabular}

Tabel 18. Kondisi eksisting kapasitas rangkaian di jam sibuk

\begin{tabular}{|c|c|c|c|c|c|c|c|}
\hline No & Variabel & Tipe & $\mathrm{N}$ & Rataan & $\begin{array}{l}\text { Selisih } \\
\text { Rataan }\end{array}$ & $\alpha$ & $\begin{array}{c}\alpha \leq 0,05 \\
(\text { Ya/Tidak })\end{array}$ \\
\hline \multirow{2}{*}{1} & \multirow{2}{*}{$\begin{array}{l}\text { Seluruh rangkaian kereta tidak } \\
\text { terisi penuh pada jam sibuk }\end{array}$} & $\mathrm{L}$ & 48 & 1,52 & $-0,979$ & $<0,001$ & $\mathrm{Ya}$ \\
\hline & & W & 52 & 1,35 & 1,154 & $<0,001$ & $\mathrm{Ya}$ \\
\hline \multirow[b]{2}{*}{2} & \multirow{2}{*}{$\begin{array}{l}\text { Antrian di stasiun tidak menjadi } \\
\text { panjang pada jam sibuk saat } \\
\text { menunggu kereta datang }\end{array}$} & $\mathrm{L}$ & 48 & 1,63 & $-0,875$ & $<0,001$ & $\mathrm{Ya}$ \\
\hline & & $\mathrm{W}$ & 52 & 1,56 & $-0,942$ & $<0,001$ & $\mathrm{Ya}$ \\
\hline \multirow[b]{2}{*}{3} & \multirow{2}{*}{$\begin{array}{c}\text { Penumpang tidak harus } \\
\text { berdesak-desakan untuk naik } \\
\text { dan selama berada dalam kereta }\end{array}$} & $\mathrm{L}$ & 48 & 1,75 & $-0,750$ & $<0,001$ & $\mathrm{Ya}$ \\
\hline & & $\mathrm{W}$ & 52 & 1,60 & $-0,904$ & $<0,001$ & $\mathrm{Ya}$ \\
\hline \multirow{2}{*}{4} & \multirow{2}{*}{$\begin{array}{l}\text { Waktu kedatangan kereta tidak } \\
\text { membutuhkan waktu yang lama }\end{array}$} & $\mathrm{L}$ & 48 & 2,56 & 0,063 & 0,632 & Tidak \\
\hline & & W & 52 & 2,48 & $-0,019$ & 0,881 & Tidak \\
\hline
\end{tabular}

Pada Tabel 19 hasil yang diperoleh untuk variabel nomor 1 dan 2 nilai rataannya jauh dibawah 2,5 dan nilai $\alpha$ signifikan terhadap 0,05. Hal ini berarti kondisi eksisting yang terjadi adalah gerbong khusus wanita terisi penuh pada jam sibuk dan tempat duduk dalam gerbong tidak cukup menampung seluruh penumpang. Variabel 3 dan 4 memiliki nilai rataan diatas 2,5 dan nilai $\alpha$ signifkant terhadap 0,05 , artinya pada kenyataanya tempat duduk prioritas baik di gerbong khusus ataupun gerbong umum sudah dipergunakan sesuai fungsinya. Sedangkan untuk variabel nomor 5 memiliki nilai rataan diatas 2,5 dan nilai $\alpha$ yang signifikan terhadap 0,05 untuk responden laki-laki tetapi tidak 
signifikan untuk responden wanita. Hal ini berarti para responden setuju penumpang wanita lebih mudah mendapat duduk di gerbong umum.

Tabel 19. Kondisi eksisting kapasitas gerbong di jam sibuk

\begin{tabular}{|c|c|c|c|c|c|c|c|}
\hline No & Variabel & Tipe & $\mathrm{N}$ & Rataan & $\begin{array}{l}\text { Selisih } \\
\text { Rataan }\end{array}$ & $\alpha$ & $\begin{array}{c}\alpha \leq 0,05 \\
\text { (Ya/Tidak) }\end{array}$ \\
\hline \multirow{2}{*}{1} & \multirow{2}{*}{$\begin{array}{l}\text { Gerbong khusus wanita terisi penuh pada } \\
\text { saat jam sibuk }\end{array}$} & $\mathrm{L}$ & 48 & 1,63 & $-0,875$ & $<0,001$ & $\mathrm{Ya}$ \\
\hline & & W & 52 & 1,33 & $-1,173$ & $<0,001$ & $\mathrm{Ya}$ \\
\hline \multirow{2}{*}{2} & \multirow{2}{*}{$\begin{array}{l}\text { Tempat duduk dalam gerbong cukup } \\
\text { menampung seluruh penumpang }\end{array}$} & $\mathrm{L}$ & 48 & 2,00 & $-0,500$ & $<0,001$ & $\mathrm{Ya}$ \\
\hline & & $\mathrm{W}$ & 52 & 1,83 & $-0,673$ & $<0,001$ & $\mathrm{Ya}$ \\
\hline \multirow{2}{*}{3} & \multirow{2}{*}{$\begin{array}{l}\text { Tempat duduk prioritas digunakan sesuai } \\
\text { fungsinya di gerbong umum }\end{array}$} & $\mathrm{L}$ & 48 & 2,79 & 0,292 & $<0,001$ & $\mathrm{Ya}$ \\
\hline & & W & 52 & 2,69 & 0,192 & 0,128 & Ya \\
\hline \multirow{2}{*}{4} & \multirow{2}{*}{$\begin{array}{l}\text { Tempat duduk prioritas digunakan sesuai } \\
\text { fungsinya di gerbong khusus }\end{array}$} & $\mathrm{L}$ & 48 & 2,81 & 0,313 & $<0,001$ & $\mathrm{Ya}$ \\
\hline & & $\mathrm{W}$ & 52 & 2,90 & 0,404 & 0,001 & $\mathrm{Ya}$ \\
\hline \multirow{2}{*}{5} & \multirow{2}{*}{$\begin{array}{l}\text { Penumpang wanita lebih mudah mendapat } \\
\text { tempat duduk di gerbong umum }\end{array}$} & $\mathrm{L}$ & 48 & 2,90 & 0,396 & $<0,001$ & $\mathrm{Ya}$ \\
\hline & & W & 52 & 2,60 & 0,096 & 0,562 & Tidak \\
\hline
\end{tabular}

Analisis berikutnya dilakukan dengan tujuan untuk mengetahui tingkat kepentingan alternatif upaya yang ada untuk meningkatkan fasilitas gerbong khusus wanita pada KRL Commuter Line di Jabodetabek. Analisis ini dilakukan dengan metode AHP (Analytic Hierarchy Process) dengan bantuan software Expert Choice. Perhitungan manual juga akan dilakukan untuk memvalidasi hasil yang diperoleh dari software Expert Choice. Responden pada bagian analisis ini berjumlah 100 orang yang terbagi menjadi 48 responden laki-laki dan 52 responden wanita serta gabungan keduanya. Ada 4 pilihan alternatif upaya yang dapat dilakukan untuk meningkatkan fasilitas gerbong khusus wanita. Alternatif tersebut adalah penambahan tempat duduk prioritas, penambahan gerbong khusus wanita, penambahan frekuensi datangnya kereta, dan penambahan jumlah petugas. Analisis yang dilakukan dengan bantuan software Expert Choice akan menampilkan nilai bobot dan nilai Inconsistency / Consistency Ratio (CR) untuk setiap jenis responden. Hasil penelitian untuk responden laki-laki dapat dilihat Gambar 1, responden wanita pada Gambar 2, dan responden gabungan pada Gambar 3 serta rangkuman hasil dapat dilihat pada Tabel 20.

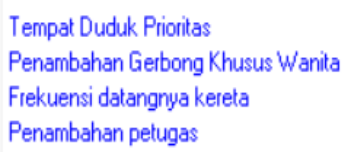

Consistency Ratio (CR): 0,03

Gambar 1. Hasil tingkat kepentingan upaya meningkatkan fasilitas gerbong khusus wanita menurut responden lakilaki $(\mathrm{N}=48)$

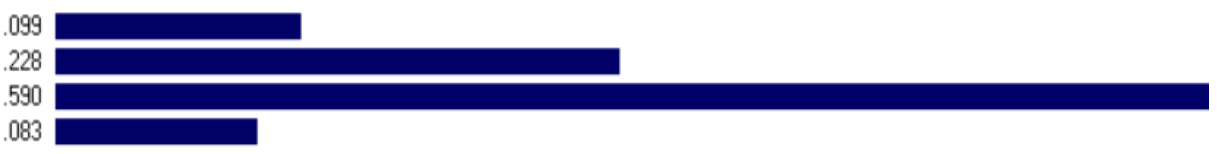

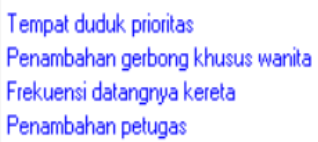

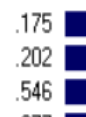

Consistency Ratio (CR): 0,05

Gambar 2. Hasil tingkat kepentingan upaya meningkatkan fasilitas gerbong khusus wanita menurut responden wanita $(\mathrm{N}=52)$

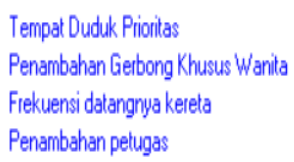

Tempat Duduk Prionitas

Penambahan Gerbong Khusus Wanita

Frekuensi datangnya kereta

Penambahan petugas

Consistency Ratio (CR): 0,03
Gambar 3. Hasil tingkat kepentingan upaya meningkatkan fasilitas gerbong khusus wanita menurut responden gabungan $(\mathrm{N}=100)$ 
Tabel 20. Rangkuman hasil AHP upaya meningkatkan fasilitas gerbong khusus wanita

\begin{tabular}{cccccccc}
\hline No & Variabel & Laki-Laki & Rank & Wanita & Rank & Gabungan & Rank \\
\hline 1 & Tempat Duduk Prioritas & 0,175 & 3 & 0,099 & 3 & 0,132 & 3 \\
2 & Gerbong Khusus Wanita & 0,202 & 2 & 0,228 & 2 & 0,211 & 2 \\
3 & Frekuensi Datangnya Kereta & 0,546 & 1 & 0,590 & 1 & 0,576 & 1 \\
4 & Penambahan Jumlah Petugas & 0,077 & 4 & 0,083 & 4 & 0,081 & 4 \\
\hline
\end{tabular}

Pada Tabel 20 dapat dilihat bahwa peringkat tingkat kepentingan upaya untuk meningkatkan fasilitas gerbong khusus wanita antara responden laki-laki, wanita, dan gabungan adalah sama dengan pilihan frekuensi datangnya kereta menjadi pilihan utama dengan nilai yang terpaut cukup jauh dari pilihan lainnya. Para responden menilai bahwa ketika jam sibuk suatu rangkain kereta tidak memiliki kapasitas yang cukup untuk menampung seluruh penggunya, sehingga dengan penambahan frekuensi datangnya kereta membuat mobilitas berjalan lebih cepat dan kapasitas pengguna juga meningkat. Untuk peringkat kedua pilihan yang dipilih adalah penambahan gerbong khusus wanita. Mengingat bahwa jumlah responden wanita berjumlah lebih banyak dan menyatakan bahwa penumpang wanita merasa aman dan nyaman di gerbong khusus wanita bisa menjadi alasan pilihan ini dirasa cukup penting setelah pilihan pertama. Pilihan berikutnya adalah penambahan tempat duduk prioritas, yang mana pada kondisi eksisting dinyatakan sudah digunakan sesuai fungsinya membuat penambahan tempat duduk prioritas memungkinkan para pengguna berkebutuhan khusus dapat ikut menggunakan moda transportasi KRL Commuter Line. Pilihan terakhir adalah penambahan jumlah petugas. Para responden memberikan peringkat terakhir pada tingkat kepentingan upaya meningkatkan fasilitas gerbong khusus wanita dengan selisih nilai yang cukup kecil. Pilihan ini mungkin didasari bahwa layanan petugas untuk kondisi eksisting sudah cukup baik sehingga tidak diperlukannya penambahan petugas.

\section{KESIMPULAN DAN SARAN}

\section{Kesimpulan}

Berdasarkan penelitian dan pengujian yang sudah dilakukan maka diperoleh kesimpulan sebagai berikut:

Kondisi eksisting sarana dan prasarana KRL Commuter Line layanan petugas di gerbong khusus wanita sudah cukup baik, yang berarti gerbong khusus wanita bebas dari tindakan kriminalitas, pelecehan (verbal dan seksual), serta kondisi kebersihan gerbong yang memadai. Perilaku penumpang di gerbong khusus terbebas dari kekerasan fisik antar penumpang, dan penumpang merasa aman dan nyaman berada di gerbong khusus wanita. Bagaimanapun, masih terjadi adu mulut antar penumpang untuk memperebutkan tempat duduk, dan penumpang harus berdesak-desakan saat naik dan berada di dalam gerbong. Sistem informasi yang tersediapun sudah cukup baik artinya kedatangan kereta terjadwal dan tepat waktu, terdapat pengumuman rute kereta, pengumuman setiap tiba di stasiun, pembeda antara gerbong umum dan khusus, serta larangan selama berada di dalam gerbong. Kapasitas rangkaian yang tersedia belum cukup memenuhi kebutuhan pengguna, terlebih pada jam sibuk. Kereta selalu terisi penuh dan antrian menjadi panjang, penumpang harus berdesak-desakan, dan kedatangan kereta membutuhkan waktu yang lama. Kapasitas gerbong juga belum mencukupi kebutuhan, seperti gerbong khusus wanita yang terisi penuh, tempat duduk yang tidak cukup menampung penumpang. Walau begitu fasilitas tempat duduk prioritas baik di gerbong umum maupun khusus sudah digunakan sesuai fungsinya. Perilaku penumpang wanita lebih mudah mendapat tempat duduk di gerbong umum juga terjadi yang artinya para pengguna wanita lebih diutamakan pada moda transportasi ini. Fasilitas gerbong khusus wanita dengan kondisi eksistingnya yang demikian dapat ditingkatkan pelayanan dan fasilitasnya. Berdasarkan hasil penelitian diperoleh prioritas kepentingan upaya untuk meningkatakan fasilitas gerbong khusus wanita adalah:

\section{Penambahan Frekuensi datangnya kereta}

2. Penambahan gerbong khusus wanita

3. Penambahan tempat duduk prioritas

4. Penambahan jumlah petugas

Persepsi responden pria maupun wanita pada saat menentukan tingkat kepentingan sudah sama.

\section{Saran pemanfaatan penelitian}

Penelitian ini dapat dimanfaatkan sebagai pertimbangan dalam perancangan dan perencaan moda transportasi umum di daerah Jabodetabek dan perbaikan sarana dan prasarana transportasi KRL Commuter Line yang sudah tersedia. Hasil penelitian ini dapat digunakan sebagai bahan tinjauan pustaka untuk penelitian selanjutnya yang mempunyai tema serupa dengan penelitian ini. Hasil penelitian ini dapat digunakan untuk pertimbangan penambahan atau 
pergantian peraturan pemerintah agar KRL Commuter Line dapat menjadi moda transportasi yang lebih baik. Tingkat kepentingan dari hasil penelitian upaya untuk meningkatkan fasilitas gerbong khusus wanita dapat menjadi acuan dan dijalankan agar keinginan dan kebutuhan para pengguna KRL Commuter Line lebih diperhatikan.

\section{Saran terhadap penelitian selanjutnya}

Jumlah responden antara laki-laki dan wanita disesuaikan dengan presentasi jumlah penumpang KRL Commuter Line harian. Penelitian lebih lanjut terhadap pilihan penambahan jumlah petugas tidak diutamakan dalam tingkat kepentingan upaya peningkatan fasilitas gerbong khusus wanita. Penyebaran kuesioner dilakukan secara langsung dan dilakukan di lakukan di stasiun KRL besar yang merupakan stasiun transit beberapa rute.

\section{DAFTAR PUSTAKA}

A. Ilyas, "Proxemics Dalam Ruang Publik Perkotaan: Studi Mode Choice Pada Masyarakat Penglaju Jabodetabek," Indonesian Journal of Sociology and Education Policy 2 (1), pp. 48 - 69, 2018.

E. T. Hall, The Hidden Dimension., New York: Anchor Books, 1966.

J. Babinard, J. Hine, S. Ellis and S. Ishihara, Mainstreaming gender in road transport: operational guidance for World Bank staff (English). Transport paper series; no. TP-28. Washington, DC: World Bank., 2010.

Masri, H. Analisis Pengaruh Faktor-Faktor Kualitas Pelayanan Terhadap Kepuasan Pelanggan Jasa Transportasi Kereta Api (Studi Kasus Pada PT Kereta Api Indonesia Daop IV Semarang). Semarang: Universitas Diponegoro, 2002

U. Husein, Metodologi Penelitian: Aplikasi dalam Pemasaran, Jakarta: Gramedia Pustaka Utama, 2003.

W. Ispurwanto and V. W. Pricillia, "Analisis Kepuasan Penumpang Gerbong Kereta Api Khusus Wanita Menggunakan Model Servqual," Bina Nusantara University, Jakarta, 2011. 
Kajian Manfaat Gerbong Khusus Wanita di

Jonathan Saliman, et al. KRL Commuter Line Jabodetabek 